\title{
Fun Science: Roket Air Sebagai Media Edu-Sains untuk Meningkatkan Motivasi Belaj ar Peserta Didik Sekolah Dasar
}

\author{
Pina Pitriana ${ }^{1 *}$, Rena Denya Agustina ${ }^{2}$, Rizki Zakwandi ${ }^{3}$, Muhammad ljharudin ${ }^{4}$, dan \\ Dede Trie Kurniawan ${ }^{5}$ \\ 1,2,3,4 Program Studi Pendidikan Fisika, Fakultas Tarbiyah dan Keguruan, UIN Sunan Gunung Djati Bandung \\ JI. A.H. Nasution No. 105, Bandung 40164 \\ ${ }^{5}$ Fakultas Keguruan dan IImu Pendidikan, Universitas Swadaya Gunung Djati Cirebon \\ Jl. Pemuda No.32, Sunyaragi, Kesambi, Kota Cirebon, Jawa Barat 45132 \\ *E-mail: pina.pitriana@uinsgd.ac.id
}

\begin{abstract}
Abstrak
Pembelajaran sains merupakan pembelajaran yang tergolong sulit dan rumit bagi mayoritas peserta didik karena memerlukan kemampuan penalaran dan imajinasi yang cukup tinggi. Penelitian ini bertujuan untuk meningkatkan motivasi peserta didik di Sekolah Dasar untuk mempelajari sains dengan menggunakan pola pelatihan pembuatan roket air yang diselingi dengan game. Hasil penelitian yang dilakukan menunjukan bahwa terdapat peningkatan motivasi belajar peserta didik pada mata pelajaran sains. Desain pelatihan dan game yang mengadopsi pembelajaran PAKEM menunjukkan respon positif dan peningkatan motivasi peserta didik terhadap pembelajaran yang ditunjukkan dengan aktifitas belajar yang meningkat. Hasil penelitian menunjukan bahwa lebih dari $90 \%$ atau mayoritas peserta didik memberikan respon positif terhadap pembelajaran serta mampu meningkatkan motivasi dan aktifitas belajar peserta didik selama proses pembelajaran.
\end{abstract}

Kata kunci: Roket air, game edukasi, media pembelajaran, pembelajaran PAKEM.

\begin{abstract}
Learning science is considered to be difficult and complicated for most students since it requires high reasoning and imagination. This study aims to increase the motivation of students in Primary School to learn science using water rockets interspersed with game. The results of the research show that there is an increase in learning motivation of learners in Lesson Subject. The design of training and games connected with PAKEM shows a positive and intensive response for students. The results showed that more than $90 \%$ of the learners provide a positive response to learning. In addition, students' motivation and learning activities were improved during the learning process.
\end{abstract}

Keywords: Water rocket, educational game, learning media, PAKEM learning.

\section{PENDAHULUAN}

Pembelajaran sains merupakan pembelajaran yang tergolong sulit dan rumit bagi mayoritas peserta didik akan tetapi memiliki daya tarik tersendiri bagi peserta didik. Berdasarkan wawancara dan observasi awal dengan pihak sekolah diperoleh hasil bahwa kecendrungan peserta didik tidak senang dengan pembelajaran sains. Hasil ini juga didukung oleh data Programme for
International Students Assessment (PISA) pada tahun 2015. Hasil yang diperoleh PISA menunjukan bahwa siswa Indonesia masih memiliki tingkat literasi sains yang rendah yang mana Indonesia menempati posisi ke 62 dari 69 negara yang dievaluasi (Iswadi, 2016). Hal ini tentunya memberikan pandangan yang kurang baik karena pada esensinya pembelajaran sains ditingkat Sekolah Dasar bertujuan untuk mempersiapkan peserta didik untuk melihat segala sesuatu dari sudut pandang logika 
(Astuti, Sunarno, \& Sudarsiman, 2012). Sehingga kompetensi harapan dari pembelajaran sains di tingkat Sekolah Dasar adalah untuk menjawab tantangan ilmu pengetahuan yang sangat dekat dan membaur dengan masyarakat.

Pembelajaran sains yang membosankan dapat diatasi melalui pelaksanakan pembelajaran menggunakan metode dan teknik yang tepat dan menarik salah satunya adalah dengan menggunakan metode PAKEM (Pembelajaran Aktif Kreatif Efektif dan Menyenangkan). Pembelajaran PAKEM memfokuskan peserta didik untuk dapat aktif selama pembelajaran dengan konsep learning by doing dan fun learning. Berdasarkan hasil penelitian yang dilakukan oleh Widiyatmoko (2012) menunjukan bahwa konsep fun learning memberikan hasil yang lebih signifikan dibandingkan pembelajaran formal yang mana pemetaan kemampuan peserta didik setelah melalui pembelajaran sains dengan konsep learning by doing dan fun learning mencapai tahap adaptasi, sedangkan pada pembelajaran formal hanya mencapai pada tahu dan melakukan saja.

Penelitian lainnya yang berkaitan dengan pembelajaran sains menggunakan fun learning adalah Astuti dkk (2012), Sunarti dkk (2017), Maleso dkk (2017), Hyungsung Park (2012) dan Yien dkk (2011) yang melakukan penelitian terhadap hasil belajar, motivasi, dan kemampuan psikomotor peserta didik. Secara keseluruhan hasil penelitian yang telah dilakukan menunjukan bahwa penggunaan media dan pembelajaran berbasis game edukasi mampu meningkatkan motivasi, kemampuan belajar dan hasil belajar peserta didik.

Mayoritas penelitian yang telah dilakukan sebelumnya menunjukkan bahwa dibutuhkan media atau alat bantu untuk meningkatkan kemampuan peserta didik secara khusus ataupun hasil belajar secara umumnya. Penelitian ini bertujuan untuk mengamati respon peserta didik terhadap pembelajaran sains dengan memanfaatkan media berupa roket air.

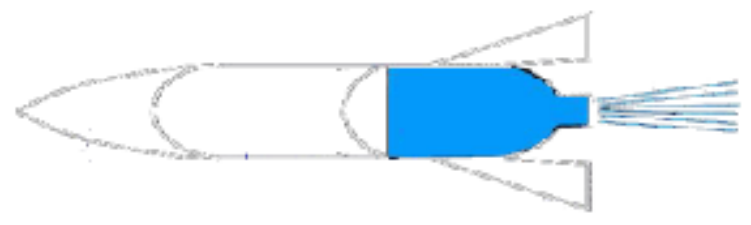

Gambar 1. Bentuk Penampang Roket Air
(dokumen penulis)
Roket air merupakan instrumen sederhana yang beroperasi mengikuti hukumhukum dalam fisika. Sejauh ini roket air telah dijadikan sebagai suatu wahana permainan belaka. Padahal jika dianalsisis secara konsep gerak yang terdapat dalam roket air terdapat kajian yang cukup kompleks baik secara fisis ataupun matematis. Bentuk penampang roket air yang dibuat dan digunakan pada penelitian ini ditunjukkan pada Gambar 1. Penelitian terdahulu terkait roket air diantaranya yaitu perancangan roket air dari barang bekas (Barjah, Sambas, \& WS, 2012), penganalisisan konsep fisika dalam gerak roket air (Haryani, Amaliah, Fitrasari, \& Viridi, 2016), dan perlombaan roket air untuk pembelajaran (Irawati, 2016)

Dari banyak penelitian yang dilakukan terkait roket air masih minim pembahasan mengenai fungsi dari roket air dalam pembelajaran sains khususnya di tingkat Sekolah Dasar. Roket air dalam pembelajaran sains memiliki korelasi dengan pembelajaran PAKEM. Hal ini karena pengenalan roket air dengan fun learning yang memuat konsepkonsep fisika dapat menarik perhatian belajar peserta didik. Sehigga latar belakang masalah yang diangkat dalam penelitian kali ini adalah bagaimana meningkatkan motivasi belajar peserta didik dengan memanfaatkan roket air yang terukur pada indeks respon peserta didik setelah mengikuti pembelajaran.

\section{METODE/EKSPERIMEN}

Penelitian ini dilakukan dengan beberapat tahap yaitu sepert pada gambar 1 . 
Fun Science: Roket Air Sebagai Media Edu-Sains untuk Meningkatkan Motivasi Belajar Peserta Didik Sekolah Dasar

Pina Pitriana, Rena Denya Agustina, Rizki Zakwandi, Muhammad ljharudin, dan Dede Trie Kurniawan

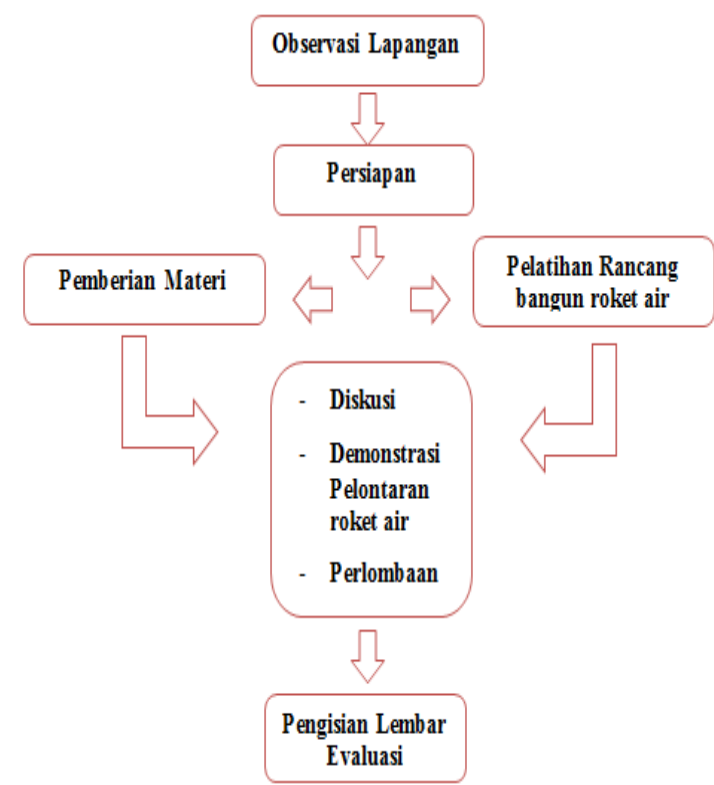

Gambar 2. Bagan Penelitian (Dokumen Penulis)

Penelitian yang dilakukan berupa kegiatan pengabdian dengan bentuk pelatihan kepada peserta didik di Sekolah Dasar Islam Terpadu (SDIT) Daarul Jihad, Kecamatan Paseh Kabupaten Bandung. Selama kegiatan dilakukan pengamatan terkait aktifitas belajar peserta didik dengan indikator meliputi keaktifan dan kerjasama peserta didik untuk membuat roket air. Kegiatan pendahuluan berupa observasi lapangan dengan melihat secara langsung kondisi subjek pelatihan, dengan observasi lapangan. Observasi lapangan dilaksanakan dengan mewawancarai Kepala Sekolah terkait keadaan peserta didik. Tahap Persiapan dilakukan dengan pembuatan dan uji coba sampel roket air hingga tahap peluncuran. Tahap pelaksanakan dilaksanakan dengan acara tatap muka, diskusi dan praktek kegiatan di lapangan. Pertemuan tatap muka menggunakan metode ceramah, demonstrasi serta praktik terbimbing dilakukan dengan berbantuan media laptop, proyektor dan bahan bahan pembuatan roket air yang telah disiapkan. Tahapan-tahapan dalam kegiatan dalam pelatihan ini adalah sebagai berikut:

1. Ceramah digunakan untuk menyampaikan pengetahuan/hal baru dan memberi penjelasan secara gamblang mengenai roket air serta merangsang peserta didik untuk belajar mandiri dan menumbuhkan rasa ingin tahu tentang roket air.

2. Pelatihan pembuatan roket air ditujukan kepada peserta didik dengan melibatkan seluruh peserta pelatihan. Proses pembuatan dibimbing oleh instruktur yang terdiri dari tim pengabdian dengan rasio satu kelompok mendapat satu instruktur.

3. Diskusi atau tanya jawab digunakan untuk melengkapi hal-hal yang belum terakomodasi oleh kedua metode diatas. Dengan diskusi ini akan terjalin interaksi dan bertukar pendapat dalam memecahkan suatu masalah sehingga didapatkan kesepakatan semua yang terlibat.

4. Demonstrasi / ujicoba untuk memperlihatkan sesuatu proses atau cara kerja suatu benda yang berkenaan dengan bahan pelajaran, dalam hal ini adalah tentang roket air

5. Lomba pelontaran roket air kreasi peserta didik

6. Pengisian lembar evaluasi pelaksanaan kegiatan.

Pada tahap pembuatan roket air, peserta didik dibagi kedalam 10 kelompok yang mana telah mempersiapkan peralatan untuk membuat roket air berupa botol, gunting, cutter, perekat pastik dan plastisin. Setiap kelompok dibimbing untuk membuat roket air mereka sendiri yang kemudian akan diperlombakan antar kelompok untuk mendpatkan roket dengan lontaran terjauh. Pelontar roket disediakan untuk memudahkan pelaksanaan kegiatan karena dinilai cukup sulit membuat pelontar bagi peserta didik. Tahap perlombaan roket ditujukan untuk meningkatkan daya kompetitif peserta didik. Subjek pelatihan kali ini adalah peserta didik SDIT Daarul Jihad kelas $\mathrm{V}$ dan $\mathrm{VI}$ yang berjumlah 40 orang.

Setelah melaksanakan pelatihan, peserta didik diberikan lembar evaluasi berupa angket yang memuat respon peserta didik terhadap kegiatan pelatihan ini. Analisis data dilakukan terhadap angket yang diisi oleh peserta didik dengan hasil berupa respon atau tanggapan peserta didik terhadap kegiatan pelatihan rancang bangun roket air (Chusni, 
4 | JIPFRI (Jurnal Inovasi Pendidikan Fisika dan Riset IImiah), Vol. 2 No. 1, Mei 2018

Zakwandi, Aulia, Nurfauzan, Alawiyah, \& Ariandini, 2017).

\section{HASIL DAN PEMBAHASAN}

\section{HASIL}

Pembuatan roket air dengan menggunakan barang-barang sederhana yang dilakukan oleh peserta didik dinilai cukup representatif dan sesuai dengan bentuk sampel yang diberikan. Modifikasi desain yang dibebaskan kepada peserta didik mengindikasikan bahwa peserta didik dapat berkreasi untuk menghias roket air yang telah dibuat. Selanjutnya untuk perlombaan terbang roket air menjadikan peserta didik bersemangat untuk menerbangkan roket air. Penerbangan roket air yang harus dilakukan secara berkelompok menuntut kerjasama yang baik antar tim. Berdasarkan pengamatan setidaknya setiap tim membutuhkan pengulangan antara 3-5 kali untuk dapat menerbangkan roket dengan benar. Dengan demikian dapat disimpulkan bahwa setelah dapat menerbangkan roket dengan benar maka tim telah dapat bekerjasama dengan baik.

Ketercapaian pembelajaran yang diharapkan dari penelitian ini melingkupi tiga komponen utama yaitu 1) ketercapaian tujuan pelatihan, 2) ketersampaian materi, dan 3) kemampuan peserta didik untuk memahami prinsip kerja dari roket air dan tata cara pembuatannya. Secara keseluruhan ketiga aspek tersebut memperoleh nilai dengan kategori baik.

Hasil wawancara dengan guru dan pihak sekolah yang dilakukan setelah melaksakan pembelajaran menunjukan hasil yang positif dimana peserta didik memiliki semangat dan rasa ingin tahu yang lebih besar terkait pembelajaran sains. Pada penelitian ini data peningkatan motivasi belajar hanya diperoleh secara kualititatif berdasarkan hasil wawancara dengan guru.

Selanjutnya aspek respon peserta didik terhadap pembelajaran fun learning yang dilaksanakan. Ditunjukkan pada Tabel 1.
Tabel 1. Pernyataan Angket dan Persentase Respon Siswa

\begin{tabular}{clcc}
\hline \multirow{2}{*}{ No } & \multicolumn{1}{c}{ Pernyataan } & \multicolumn{2}{c}{ Jawaban (\%) } \\
\cline { 2 - 3 } & & Ya & Tidak \\
\hline 1 & $\begin{array}{l}\text { Pelatihan Roket Air ini } \\
\text { berlangsung sangat } \\
\text { menarik }\end{array}$ & 100 & 0 \\
& $\begin{array}{l}\text { Kesempatan berdiskusi } \\
\text { dalam pelatihan ini, } \\
\text { membuat saya lebih } \\
\text { berani mencoba } \\
\text { bereksperimen } \\
\text { Dengan cara pelatihan } \\
\text { seperti ini, membuat } \\
\text { saya bisa belajar } \\
\text { bekerjasama dengan } \\
\text { teman }\end{array}$ & 85 & 15 \\
$\begin{array}{l}\text { Cara belajar pelatihan } \\
\text { ini, menjadikan saya } \\
\text { senang belajar }\end{array}$ & 85 & 5 \\
$\quad \begin{array}{l}\text { Cara belajar pelatihan } \\
\text { ini, membuat saya } \\
\text { mengerti Manfaat } \\
\text { mempelajari sains }\end{array}$ & 95 & 5 \\
\hline
\end{tabular}

\section{PEMBAHASAN}

Berdasarkan data penelitian pada (tabel/gambar) menunjukan hasil bahwa lebih dari $90 \%$ atau mayoritas peserta didik memberikan respon positif terhadap pembelajaran. Hasil analisis angket menujukan bahwa sebagian besar peserta didik mengungkapkan bahwa kegiatan pelatihan ini memuaskan mereka. Mayoritas peserta didik mengungkapkan bahwa kegiatan ini menyenangkan, seru dan bagus karena mereka bisa belajar sambil bermain. Berdasarkan hasil penelitian (Marscella, 2017) hal tersebut termasuk dalam kategori respon yang sangat baik. Menurut (Wiyono, 2009) dengan adanya tanggapan peserta didik terhadap pembelajaran dapat memperoleh informasi mengenai peserta didik menyenangi pembelajaran eksperimen yang disajikan atau tidak.

Kompetisi yang diselenggarakan membuat peserta didik mejadi tertantang untuk bisa mengikuti dan membuat sebaik mungkin roket air. Hal ini menyebabkan peserta didik berusaha untuk belajar membuat dan bekerja 
sebagai tim yang baik untuk mensukseskan misi mereka agar menjadi tim terbaik dalam perlombaan roket air ini.

Sebagian besar peserta didik mengungkapkan manfaat dari kegiatan ini adalah membuat mereka bisa bekerjasama dalam tim dalam membuat roket air. Respon peserta didik menunjukan bahwa kegiatan ini dapat mengasah kreativitas mereka dalam memanfaatkan barang bekas yang dapat digunakan sebagai sarana belajar sains. Output tambahan dari kegiatan ini adalah peserta didik mendapat manfaat berupa tambahan wawasan mengenai dunia aeordinamika secara sederhana yaitu pada peluncuran roket.

Ketercapaian target materi yang disampaikan dalam kegiatan pelatihan ini secara umum sudah sangat baik. Hal ini dapat dilihat dari angket hasil respon peserta terhadap kegiatan pelatihan secara keseluruhan atau tiap materi. Lebih dari $75 \%$ peserta mengungkapkan kegiatan pelatihan ini bagus untuk kelengkapan materi, dan $80 \%$ mengungkapkan bahwa kegiatan pelatihan ini memuaskan mereka dari segi kelengkapan materi yang dsainsparkan.

Pencapaian target materi dinilai dengan hasil angket peserta didik terkait pemateri. Sebagian besar peserta didik mengungkapkan bahwa pemateri menyampaikan materi dengan menarik dan mudah dsainshami, baik mengenai materi konsep prinsip kerja roket maupun instruksi pembuatan roket air dan cara penggunaan pelontarnya. Keterbatasan dari penyampaian pemateri adalah terkait tempo penyampaian yang terlalu cepat. Hal tersebut dapat teratasi dengan penambahan instruktur kegiatan yang merangkap sebagai pemateri paralel dan pembimbing bagi peserta didik.

Penyebaran angket terkait pembuatan dan penerbangan hasil karya menunjukan respon yang juga bernilai positif. Hal ini diindikasikan dengan sebagian besar peserta didik mengungkapkan bahwa bagian yang paling disenangi adalah saat mencoba menerbangkan roket air yang telah mereka buat. Hal ini disebabkan karena pada saat menerbangkan roket ada kompetensi untuk bisa melontarkan sejauh mungkin yang bisa mereka lakukan. Respon yang diberikan mengindikasikan bahwa terdapat peningkatan motivasi belajar yang disebabkan oleh kompetisi yang diadakan. Hasil serupa juga dikemukakan oleh Park (Park, Relationship between Motivation and Student's Activity on Educational Game, 2012) yang juga meneliti tentang korelasi antara efektifitas pembelajaran dengan menggunakan game.

Kemampuan peserta dalam memahami prinsip kerja roket air dan langkahlangkah pembuatan dengan menggunakan pelontar roket air dapat dikategorikan baik. Hal ini dapat terlihat dari diskusi dan praktik pembuatan roket air yang dilakukan peserta didik. Sebagian besar peserta didik mengungkapkan bahwa roket air ini bisa terbang karena adanya tekanan udara sampai udara menekan air sehingga semburan air ini menjadi gaya dorong roket untuk bergerak meninggalkan pelontarnya.

Melalui kegiatan ini sebagian besar peserta didik berpendapat belajar sains perlu banyak melakukan aktivitas seperti praktik yang menyenangkan. Hal ini mengindikasikan bahwa pembelajaran sains melalui fun learning dapat meningkatkan motivasi belajar peserta didik. Respon peserta didik secara umum menyatakan bahwa mereka menginginkan kegiatan belajar sains seperti belajar sambil bermain seperti pelatihan pembuatan roket air, dan demonstrasi kegiatan alam menggunakan video yang dilanjutkan dengan praktik sederhana dalam memahami pelajaran sains yang diberikan disekolah.

\section{PENUTUP}

Secara keseluruhan kegiatan pelatihan ini dapat dikategorikan berhasil dengan melihat pencapaian yang telah didapatkan. Secara garis besar peserta didik dapat mengambil banyak manfaat dari kegiatan pelatihan ini. Hal ini terungkap dari respon yang diungkapkan melalui angket yang pada umumnya berisikan 
6 | JIPFRI (Jurnal Inovasi Pendidikan Fisika dan Riset IImiah), Vol. 2 No. 1, Mei 2018

komentar positif. Hasil wawancara yang dilakukan menyatakan bahwa terdapat peningkatan motivasi belajar peserta didik pada mata pelajaran sains yang diindikasikan dengan rasa ingin tahu yang meningkat dan semangat belajar yang tinggi. Berdasarkan analisis data pada angket respon peserta didik, dapat disimpulkan bahwa dengan pelatihan rancang bangun roket air ini pembelajaran sains menjadi menyenangkan sehingga ketercapaian target materi pada pelatihan ini memperoleh kategori sangat baik. Maka disarankan agar pembelajaran sains dibuat hingga peserta didik merasa senang saat melaksanakan pembelajaran, seperti sedang bermain padahal peserta didik sedang belajar.

\section{UCAPAN TERIMAKASIH}

Peneliti mengucapkan terimakasih kepada LP2M UIN Sunan Gunung Djati Bandung atas Hibah dana Penelitian dan Pengabdian di Sekitar Kampus tahun 2017 dan Kepada pihak SDIT Darul Jihad atas partisipasi dalam pelaksanaan pelatihan dan penelitian.

\section{DAFTAR PUSTAKA}

Astuti, R., Sunarno, W., \& Sudarsiman, S. (2012). Pembelajaran sains dengan pendekatan keterampilan proses sains menggunakan metoda eksperimen bebas termodifikasi dan eksperimen terbimbing ditinjau dari sikap ilmiah dan motivasi belajar siswa. Jurnal Inkuiri, 1(1), 51-59.

Barjah, N. N., Sambas, A., \& WS, M. S. (2012). Rancang bangun alat eksperimen roket air dari barang bekas sebagai media pembelajaran mekanika. Prosiding Pertemuan IImiah XXV HFI Jateng \& DIY (pp. 186-189). Purwokerto: Pusat Teknologi Akselerator dan Proses Bahan Badan Tenaga Nuklir Nasional.

Chusni, M. M., Zakwandi, R., Aulia, M. R., Nurfauzan, M. F., Alawiyah, T. A., \& Ariandini, S. (2017). Pelatihan Rancang Bangun Media Pembelajaran
Mobile Learning Berbasis Android untuk Meningkatkan Kompetensi Pedagogik Guru Madrasah. Tarbiyatuna, 94-103.

Haryani, F. F., Amaliah, R., Fitrasari, D., \& Viridi, S. (2016). Konsep fisika dalam gerak permainan roket air. Seminar Nasional Pendidikan Sains (pp. 245254). Surakarta: Universitas Sebelas Maret.

Irawati, I. (2016). Lomba Roket Air: Penerapan pembelajaran fisika berbasis proyek. Seminar Nasional Fisika. 5, pp. 29-34. Jakarta: Universitas Negeri Jakarta.

Maleso, A., Syamsuddin, \& Satosa, P. B. (2017). Penggunaan media gamba dalam meningkatkan kemampuan menulis paragraf sederhana siswa kelas III SDN Inpres Labangun Kecamatan Buko Selatan. Jurnal Kreatif Taduloka Online, 5(10), 65-77.

Marscella, F. A. (2017). Pengembangan alat peraga fisika sederhana berupa termoskop untuk pembelajaran materi termodinamika. Lampung: UIN Raden Intan.

Park, H. (2012, March). Relationship between Motivation and Student's Activity om Educational Game. International Journal of Grid and Distributed Computating, 5(1), 101-113.

Park, H. (2012). Relationship between Motivation and Student's Activity on Educational Game. International Journal of Grid and Distributed Computing, 101-114.

Sunarti, Jamhari, M., \& Lilies. (2017). Meningkatkan hasil belajar sains dengan menggunakan media gambar untuk kelas IV di SDN Gallange Desa Lempe KecDampal Selatan Kabupaten Tolitoli. Jurnal Kreatif Taduloka Online, 5(10), 118-132.

Widiyatmoko, A. (2012). Pengembangan perangkat pembelajaran sains Fisika dengan pendekatan Physics- 
Edutaiment berbantuan CD Interaktif. Jurnal PrimeEdu, 1(1), 51-59.

Wiyono, K. (2009). Model Pembelajaran Multimedia Interaktif Relativitas Khusus untuk Meningkatkan Penguasaan Konsep, Keterampilan Generik Sains Siswa SMA. Jurnal Penelitian Pendidikan, 21-30.

Yien, J.-M., Hung, C.-M., Hwang, G.-J., \& Lin, Y.-C. (2011). A game-based learning approach to improving students' learning achievements in a nutrition course. The Turkish Online Journal of Educational Technology, 10(2), 1-10. 